\title{
Integrated System of Values \\ of Modern People Based on Sociological Research in the Krasnoyarsk Territory
}

\author{
Elena A. Nozdrenko*, \\ Olga F. Morozova and Elena A. Rukavitsina \\ Siberian Federal University \\ 79 Svobodny, Krasnoyarsk, 660041, Russia
}

Received 19.03.2015, received in revised form 21.04.2015, accepted 02.06.2015

The paper presents the results of sociological research as a part of the project to study the phenomenon of culture in the life of modern man. The object of the study are residents of the cities of the Krasnoyarsk Territory; the focus of the paper is social and cultural human activity aimed at creating value orientations, norms, rules of life, ideas, examples, etc. The form of sociological research is private (depth) interviews. Features of the sample: nonrandom, "first person available fit" method, the total number of respondents was 40. The aim of this study is to identify a set of value orientations, norms, attitudes of consumers that determine their meaning of life, actions and main reasons for the formation of cultural values in the modern Russian society.

On the one hand, the problem of research is a mismatch of people's demand for culture forming a man as a "product" and possibilities of cultural space. On the other hand, one needs to become a "cultural man", to define the "right" way of socialization of citizens in the society, to form such value orientations that would not only enable a person to exist within the modern society, but also cause a constant desire for self-realization, self-improvement, self-development, as well as a desire to transform the surrounding space by means of social and cultural activities.

According to the study, specified representations about the content and nature of the values indicate the ambiguous understanding of the value structure of the individual respondents. Definition of lifepurpose acts has become a part of worldview of the respondents. At the same time their very existence is doubtless, they are perceived as a natural and essential element of life. There are some signs of a rational and pragmatic type of culture, in a way contrary to the Russian mentality. Due to the high importance of ethical component for characterizing social and cultural space the authors remark on the unindifferent attitude of the respondents to the cultural and ethical relations, and the ways to stabilize and harmonize them. In the context of a multi-ethnic society there are manifested archetypal mental mindsets expressed in the concepts of "belonging" and thinking another man as a "our or alien". The paper describes the ethical relations with the aim of avoiding aggravation of a conflict. The realities of the social and cultural space of the Krasnoyarsk Territory put really important indicators, a kind of a "moral set" to the fore.

Keywords: system of values, culture, life-purpose act, social and cultural space, the Krasnoyarsk Territory, depth interview.

(C) Siberian Federal University. All rights reserved

* Corresponding author E-mail address: elena.nozdrenko@mail.ru 
The study was supported with the financial support by "Russian Humanitarian Science Foundation" (Project № 14-13-24002) and "Krasnoyarsk Regional Fund Supporting Scientific and Technical Work (Project № KФ-458). The topic was stated as "Intellectual Leisure as a Factor of Sustainable Development of Urban Areas (on the Basis of the Krasnoyarsk Territory)".

DOI: 10.17516/1997-1370-2015-8-8-1710-1723.

Research area: culture studies.

The study was conducted as a part of a project to study the phenomenon of culture in the life of modern man in order to reveal the complex of value orientations, norms, attitudes of consumers that determine their life-purpose actions and the main reasons for creating cultural values in the modern Russian society. The cluster of questions asked reflects the direction of the study, which consists of three parts: 1) the definition of "lifepurpose act"; 2) the formation of comprehensive understanding of the value system of modern man; 3) the systematization of the complex of value orientations, norms, attitudes of consumers in their minds.

The object of the study is residents of the cities of the Krasnoyarsk Territory (respondents of sociological research). The subject of the study is social and cultural human activity aimed at forming value orientations, norms, rules of existence, ideas, examples, etc.

The goal of this study is to identify a set of value orientations, norms, attitudes of consumers that determine their life-purpose actions and the main reasons for the formation of cultural values in the modern Russian society

The form of sociological research is private (depth) interviews.

For this sociological study the researchers chose a depth interview as the most appropriate method. The main feature of depth interviews is the lack of a rigid plan and questions that preset answers. Its advantage lies in the naturalness of the conversation, the possibility to adapt to the peculiarities of behavior, manners, language specifics of the respondents in a variety of communicative situations and, as a consequence, in the reliability of the data. While conducting depth interview is the authors used direct and factual, structural questions, such as a "big tour" questions; contrasting and idealizing techniques, modeling hypothetical interaction.

The features of the sample: nonrandom, "the first person available fit". The number of respondents was 40. Respondents were segmented according to the place of living: people in Krasnoyarsk, Minusinsk, Lesosibirsk, Kansk, Achinsk, Norilsk. The gender and age composition, as well as the income level of the respondents were not determinative.

The period of the study was from July to October 2014. The interviews were recorded by digital audio equipment.

List of questions for the interview:

1) What does the concept of life-purpose act mean for you? How do you understand it?

2) What (moral, material, ethical) values is the highest priority for you? Explain why.

3) If you were to choose between family, friendship, career growth, what would you choose? Why would you do this? Explain your choice.

4) How do you increase your cultural and intellectual level? Explain, please, why you do this and what you do exactly.

5) Do you think there is a cultural and ethical conflict in the modern society in Krasnoyarsk and the Krasnoyarsk Territory? What reasons lie at the heart 
of this conflict? Is it possible to avoid a cultural and ethical conflict? And if there were some conflicts, how could one get out of them?

6) How do you feel about the festive rituals of other cultures, religions, when they take place in the urban space of Krasnoyarsk?

7) How do you feel about the manifestation of feelings (kissing, hugging) in public places?

8) Recall, please, a case when you may not have acted quite ethical in relation to another person. Are you sorry about what happened? Would you like to change the situation?

In the course of depth interviews the researchers created favorable conditions for a meeting of the interviewer with respondents; the meetings were carried out in pre-agreed and convenient time for the respondent, sometimes at the territory of the organization where a respondent works. In addition, the respondents had the opportunity to ask the interviewer questions, clarifying the conceptual nuances, goals and objectives of the project. Totally 40 personal (depth) interviews were held.

List of the survey participants:

1. Ekaterina, a methodologist at Krasnoyarsk Art Institute, Krasnoyarsk (34 year old).

2. Elena, an employee at Palace of Culture, Norilsk (28 year old).

3. Marina, an employee at Central City Library, Norilsk (36 year old).

4. Natalia, an employee at Palace of Culture, Norilsk (36 year old).

5. Margarita, a student, a ballet dancer, Krasnoyarsk State Opera and Ballet Theatre, Krasnoyarsk (26 year old).

6. Anna, an employee at the Regional state budget institution of culture "House of Art”, Krasnoyarsk (28 year old).
7. Sergey, IT specialist, Krasnoyarsk (36 year old).

8. Darya, a young mother on maternity leave, Krasnoyarsk (24 year old).

9. Olga, an accountant at Krasnoyarsk Machine-Building Plant (JSC "Krasmash"), Krasnoyarsk (34 year old).

10. Sergey, head of Information Technology Department, at Krasnoyarsk MachineBuilding Plant (JSC "Krasmash"), Krasnoyarsk (35 year old).

11. Radmira, a student of Siberian Federal University, Achinsk (18 year old).

12. Evgeniia, deputy director for education and chemistry teacher at secondary school №24, Krasnoyarsk (35 year old).

13. Maria, a hairdresser, a sole entrepreneur, Krasnoyarsk (27 year old).

14. Nadezhda, a ceramics teacher at the Children's Art School №1 named after V.I. Surikov, Krasnoyarsk (27 year old).

15. Inna, an employee at Minusinsk Centralized Library System, Minusinsk (40 year old).

16. Yury, an employee at Minusinsk Centralized Library System, Minusinsk (37 year old).

17. Irina, an employee at Minusinsk Centralized Library System, Minusinsk (35 year old).

18. Anna, an employee at Minusinsk Centralized Library System, Minusinsk (43 year old).

19. Irina, a lecturer at a student of Siberian Federal University, г. Красноярск (36 year old).

20. Natalia, an employee at the Krasnoyarsk Regional Fund Supporting Scientific and Technical Work, Krasnoyarsk (57 year old). 
21. Elena, a lecturer at the Krasnoyarsk State Art Institute, Krasnoyarsk (60 year old).

22. Larisa, head of the Children's Art School №1 named after V.I. Surikov, Krasnoyarsk (57 year old).

23. Maria, a teacher of drawing at the Children’s Art School №1 named after V.I. Surikov, Krasnoyarsk (37 year old).

24. Natalia, a teacher of drawing at the Children's Art School №1 named after V.I. Surikov, Krasnoyarsk (33 year old).

25. Nadezhda, a student of Siberian Federal University, Krasnoyarsk (18 year old).

26. Alexandra, a student of Siberian Federal University, Achinsk (19 year old).

27. Victoria, a student of Siberian Federal University, Krasnoyarsk (19 year old).

28. Iulia, a student of Siberian Federal University, Krasnoyarsk (18 year old).

29. Natalia, a sole entrepreneur, Krasnoyarsk (29 year old).

30. Larisa, a methodologist at Siberian Federal University, Krasnoyarsk (28 year old).

31. Iulia, a methodologist at Siberian Federal University, Krasnoyarsk (22 year old).

32. Maria, a methodologist at Siberian Federal University, Krasnoyarsk (22 year old).

33. Ekaterina, a musicologist at Krasnoyarsk State Academy of Music and Theatre, Krasnoyarsk (27 year old).

34. Uliana, deputy director for organizational matters at "House of Cinema", Krasnoyarsk (30 year old).

35. Olga, head of Design and Information Department at "House of Cinema", Krasnoyarsk (28 year old).

36. Natalia, director of the youth center, Achinsk (34 year old).

37. Kirill, a researcher at Museum and Exhibition Center, Achinsk (24 year old).
38. Alina, an employee at the City Centralized Library System, Achinsk (43 year old).

39. Tatiana, head of the Regional state budget institution of culture "House of Art", Krasnoyarsk (28 year old).

40. Fatima, a designer-decorator, a sole entrepreneur, Krasnoyarsk (28 year old).

\section{Analytical description of the research results}

The logic of contemporary cultural studies leads science to very complicated problems associated with a variety of relations between "culture" and a "man". If culture is understood as a form of being, which is qualitatively different from the existence of nature and a man is understood as a creator and representer of this form, the question of the mechanisms of coding cultural meanings in various artifacts and deciphering these meanings during the life of an individual takes on particular importance. In this regard, knowledge of life-purpose problems merges with the cultural reflection of individual people, their representation of peace and selfrealization in this world.

As it can be seen from the analysis of the survey results, the definition oflife-purposeactions has become a component of the respondents' worldview. Meanwhile the very existence of life-purpose actions is not questioned; they are regarded as a natural and essential element of life. $99 \%$ of respondents stated the undeniable presence of this kind of actions and some people even stressed the obligatory character of such actions: everyone "has to make" such actions, any person lives for the sake of such behaviour; they do not only more determine many things, but they also they make life valuable, as seemingly deliberate "bifurcation points".

The depth of understanding in this case was different from the ordinary level: "it is, then it should exist". One should rather try the 
philosophical insight into the meaning's essence, which is partly inherent in sophistical reasoning, where everything is filled with meaning, whereas the individual perception of sense and nonsense is different, it depends on the age, education, nature. This differentiation does not detract from the existence of common meanings, shared meaning is conceived as a summand of many, even minor acts; life process is based on the universal connection of phenomena, the dialectics of necessity and contingency ("even a mosquito bite on the other side of the world can change the life of a man radically").

Representations about the meaning of behavior are connected inseparably with chronal self-determination: we do not speak here about short terms, self-awareness "here and now", but rather about understanding of all life, when a life-purpose act is perceived as a part of the activity that either determines the course of life as a whole or changes its direction, and the importance of such an act increases along with self-retrospective analysis: it must be an act about which one will not regret in old age. Life-purpose actions, although they are most often emotionally evocative, are always predetermined by ideals, principles, values.

Culture is thought as a system, all elements of which are penetrated by a "fundamental principle"; they "express only one and the main value" (P. Sorokin). Values serve as "the basis and foundation of culture", and a man as a product of the culture internalizes a universe of values in the society. The increasing relevance of studying the axiological component is caused, firstly, by the high status of value orientations underlying the models and standards of human behavior, and secondly, by the drastic change of the system of values, and thirdly, by the need to modify its targets under the influence of social and cultural dialogues on a global scale and modernization processes in the local social systems.

An analysis of the responses to the question about top-priority values leads to the conclusion that a hierarchy of values has certain originality.

The first perspective of the analysis allowed distinguishing the attitude to moral and material values. The priority was given to moral and ethical values (75\%), wealth took second place (25\%), and the choice depending on the situation was preferred by $10 \%$ of respondents (Fig. 1).

Specification of representations about the content and nature of the values indicates the ambiguous understanding of the value structure by individual respondents. So such vital values as health, physicality, and also well-being and physical condition of the person's quality of life, consumption, comfort, as well as having a family and children fell into the category of material values. The category of moral values in addition to

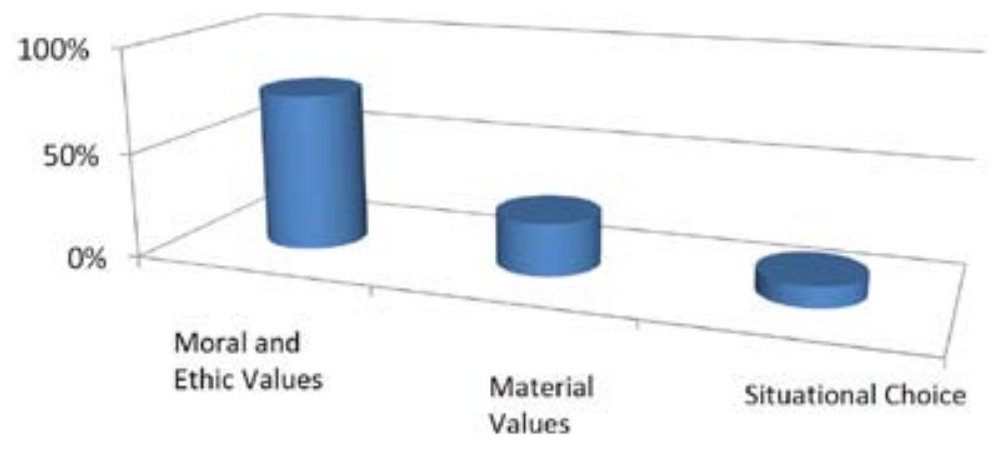

Fig. 1 Attitude to values 
Table 1. Content and nature of the values

\begin{tabular}{|l|l|l|}
\hline \multicolumn{1}{|c|}{ material values } & \multicolumn{1}{|c|}{ social values } & \multicolumn{1}{c|}{ moral values } \\
\hline $\begin{array}{l}\text { economic viability, luxury, } \\
\text { presence of housing, food, money, } \\
\text { health }\end{array}$ & $\begin{array}{l}\text { family, work, study, patriotism, } \\
\text { friendship, friendly relationships } \\
\text { with others, the ability of self- } \\
\text { development, the ability to achieve } \\
\text { the goal }\end{array}$ & $\begin{array}{l}\text { spirituality, morality, politeness, } \\
\text { happiness, honesty, loyalty, } \\
\text { sincerity, determination, openness, } \\
\text { honesty }\end{array}$ \\
\hline
\end{tabular}

the traditional ones, such as goodness, spirituality, morality, love, honesty, respect for elders, justice, mutual aid, self-improvement, comprised values of communicative relationships: respect, honesty, loyalty, patriotism and good relations in the team, as well as happiness. The researchers noted the striving to allocate universal values, values that accompany the entire life activity.

The group of respondents focused attention on the difference in moral and ethical values, even their hierarchies (moral values - ethical values and material values ), although they did not provide the reasoning of their position (Table 1). In particular there was a claim that the concepts of ethical-unethical is relative, while the moral norms are absolute, they are the same regardless of the circumstances, are indispensable for doing deeds.

The religious values did not get any coverage in structure of values; the religious values are the divine law, faith, salvation, ritual holiness, commandments. Neither the respondents named any political values, except for such value as "patriotism", the probable list of political values might include the rights and freedoms of citizens, statehood, rule of law, political governance, civil peace, civil duty, participation in politics, political interests, political culture. The aesthetic values also remained outside the focus, the respondents could have named the beauty (or aesthetics of ugliness), ideal, style, harmony, following tradition or innovation, aesthetics, cultural originality, fashion.
In most cases, the respondents did not oppose moral and material does values, they told about the transient nature of the material ("today there is some, tomorrow there won't be") and the "eternity" of morality. The interviewed noticed the relationship between values. The material values such as economic prosperity, money were not considered as an end in itself, but as a means to achieve other goals: self-improvement, career development, realization of life plans, education of children, and also as a basis for spiritual growth, education, opportunities to get involved in favorite activity. The moral values were presented as a prerequisite for communication in the community and society.

The next question predestined thinking in a different categorical field: if you were to choose between family, friendship, career growth, what would you choose? This question is focused on the three levels of social space: family - a micro-level, career growth - a level of social community and friendship - a median indicator characterizing communication. The respondents' choice indicated that the concept of "friendship" was driven out of moral principles and retained its value as an opportunity to communicate with people outside the family and professional circles. In this respect, $30 \%$ of the respondents could sacrifice friendship, the more so as the respondents are aware of that the concept of "friendship" has a different meaning today in comparison with what was in the past. Only in some cases, love and friendship appeared as 


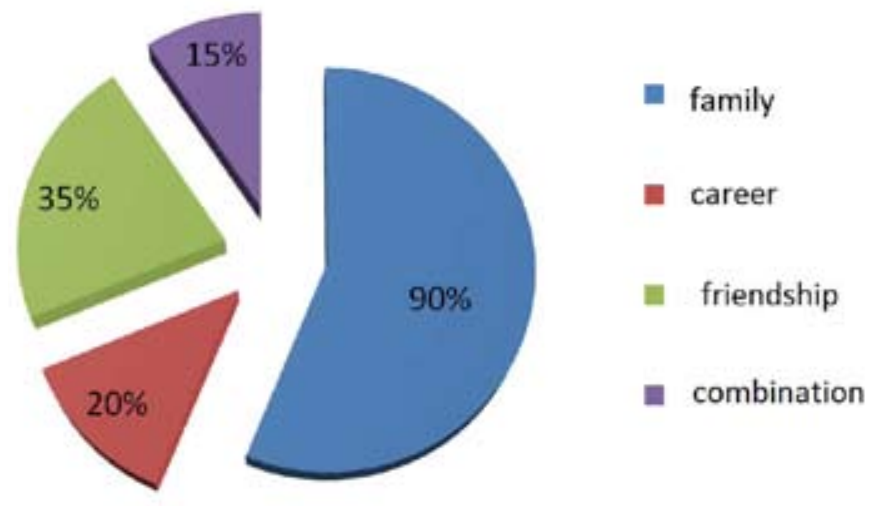

Fig. 2. Choosing between family, friendship, career growth

the basis of moral relations in the family and professional activities (Fig. 2).

The reassessment of career, family and friendship depending on age, changes of social status is noteworthy.

The was distinguished a specific situation with the following factors:

- Career development is suspended

- There are no family relationships under certain circumstances, or the family members are separated geographically.

- The respondents have been friends with some people for a long time.

In this case friendship as an opportunity to communicate and have spiritual closeness becomes a priority. Perhaps, the beliefs of the respondents depend on:

- gender (mostly women were interviewed)

- age

- social and cultural type

- education

- mental structures

$25 \%$ of respondents assigned their attitude to the values of career and family to tradition and upbringing: "I was brought up as such", "it was a tradition in our family". The researchers observed some negative attitude towards career, the respondents often used the term "social climber" as the opposite to the prevailing value system in our culture. But $18 \%$ of respondents consider their career as an opportunity for the formation, preservation, development of the family.

There were also the views inherent to rational and pragmatic type of culture and in some way contrary to the Russian mentality. The basis is the assertion that it is enough for any man to be a member of two groups: professional and "personal", although the latter notion does not define what is meant exactly: the family or circle of friends-acquaintances. The feature of mental state is evaluated with the help of concepts, such as "sufficient", "okay", rather than "happiness" or "meaning".

Several respondents noted that people do not always have to choose between career and family, they experienced the protest against the opposition of living requirements. Human activity should seek for a harmonious combination ("balance") of family and professional responsibilities. If the balance cannot be achieved, the choice has to be made under the influence of:

- life situation

- influence of others

- education

- tradition and moral principles

A man becomes a product of culture in the process of socialization and enculturation. Over $30 \%$ of respondents in their responses indicated 
a high importance of opportunities to improve the cultural and intellectual level for them. Thus, the respondents do not associate leisure with meaningless pastime, rather people strive to address in leisure activities some important cultural tasks. The respondents gave detailed answers to the question "How do you increase your cultural and intellectual level?" The researchers drew the following conclusions:

1. The need to improve the cultural and intellectual level is doubtless.

2. The cultural and intellectual levels are considered as a whole, the intellect is conceived as an integral part of culture.

3. The forms enhancing the cultural and intellectual level are not standardized and are varied (Fig. 3).

4. There are no significant differences among residents of the city and rural areas.

Thus, the vector direction of enhancing cultural and intellectual levels varies. Realization of the need to structure special - personal-cultural space implies relations with:

- a subject-corporeal world, which has a chronic structure: it is a world of cultural artifacts accumulated by mankind and serving as the basis for social and cultural determination of the individual, the sphere of created by the subject the cultural and art objects, which reflect internalized social and cultural ideals and values;

- social and cultural institutions, within which the vital activity of the individual takes place ;

- other people, in the communication process with whom a man forms the culture of social communication, acquires some ethical norms, rules, laws.

Specificity of the cities of Krasnoyarsk region, like other cities, is the high degree of decentralization of social and cultural spheres. There is no established practice of interaction

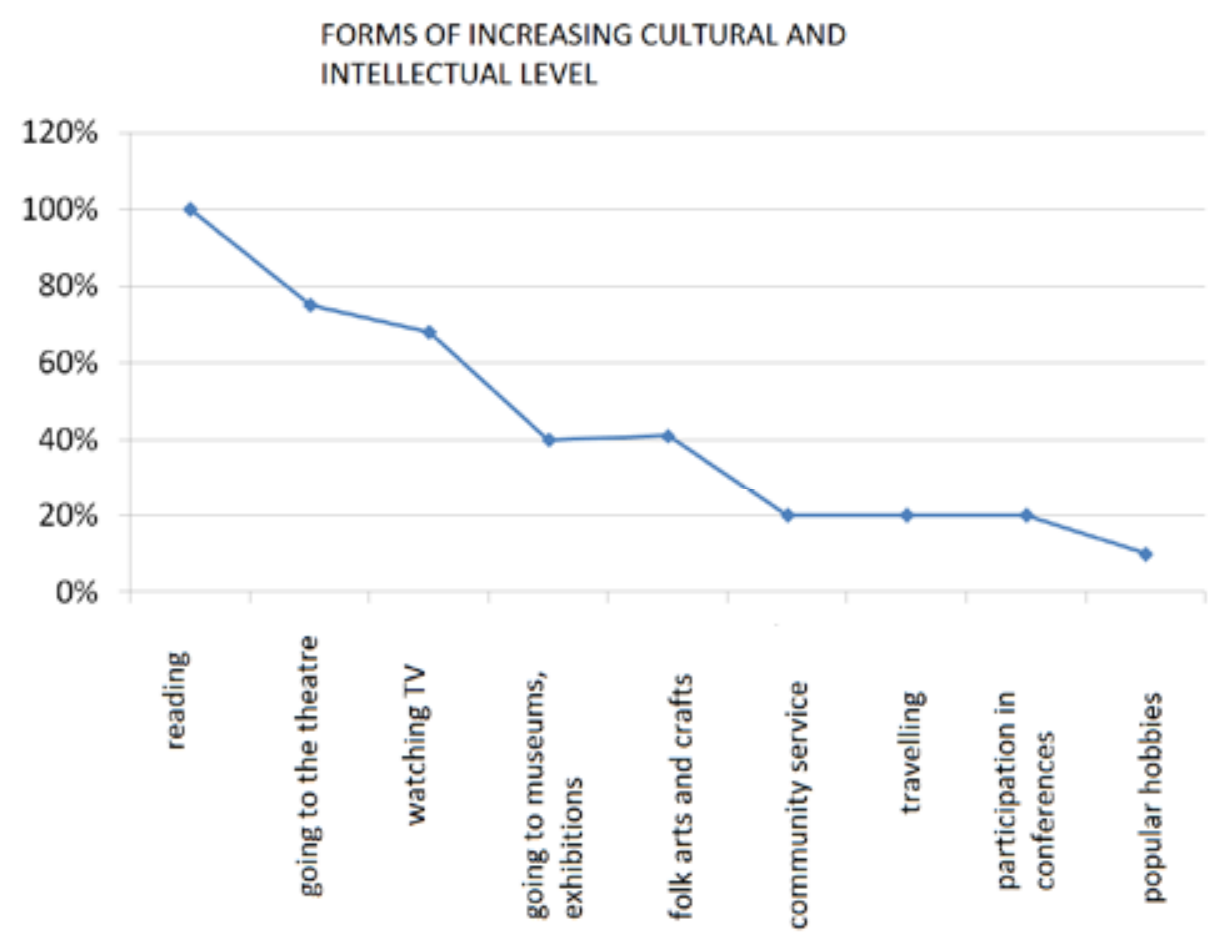

Fig. 3 The vector directions of increasing cultural and intellectual levels 
between the institutional and self-organized structures providing leisure activities.

An important regulator of relations in the social and cultural environment is morality as a system of ethical values, which expresses ideas about the proper things and things existent, right and wrong, just and unjust. The effectiveness of human communication in the world of culture raises, increasing the ability to achieve the goal only if people fully understand the moral standards and rely on them in daily life.

Due to the high importance of ethics for the characterization of social and cultural space of the city of Krasnoyarsk there is manifested unindifferent attitude of the respondents to the cultural and ethical relations, and possible ways to stabilize and harmonize them. Given the quantitative characteristics of the city's population, its multinational composition, originality of gender and age parameters, the researchers ascertain the presence of specific social and cultural situation. The relevance of the studying this situation is predetermined by the fact that Krasnoyarsk as a metropolis has united cumulative, integrative, communication and information processes, moreover, the process of making the city a kind of megalopolis led to significant changes in the structural and substantial characteristics of the city at the present stage against the background of globalization and interpenetration of cultures.

This explains why there are collisions of oppositely directed, incompatible behavioral trends, which generate negative emotional experiences, namely what is traditionally called a conflict. A common opinion of the respondents is that there is a cultural and ethical conflict (Fig. 4).

Similarly, many people believe that the conflict is something inherent to the process of social development ("without conflict there is no life"). Based on the opinion of well-known social psychologist B. Wool ("Life is a process of endless conflict resolution"), the respondents wrote about the inevitability of the collision between the interests, opinions, objectives of the representatives of different age, religious, ethnic groups. In their detailed responses the researchers observed multiple typologies of conflicts. But mostly the conflicts were divided into: interpersonal, intergroup, internal.

The reasons of the ethical conflicts:

- lack of tolerance ("illusory tolerance")

- bad manners, lack of moral and ethical principles intrinsic in people

- lack of understanding between generations

- different traditions

\section{THE PRESENCE OF CULTURAL AND ETHNIC CONFLICT}



Fig.4 The presence of cultural and ethnic conflict
There is a conflict

There is no conflict

Difficult to say 
- lack of and ill-conceived distribution of material and social benefits among various social groups

The first reason looks like a base that generates all the others. The consequence of tolerance is the relationships based on trust, a willingness to cooperate, friendliness in all respects, while intolerance begets negativity and bad relationships especially in ethnic interactions. For Krasnoyarsk particularly important abilities are perceiving different from the local cultural patterns of behavior without rejection, accepting their way of life and opinions of others. As a result of the active migration there occurs a requirement of so-called "forced tolerance" so to achieve a constructive tolerance. Only in this case, as noted by the respondents, there may be no unwanted reactions in a conflict situation.

Therefore, it is possible to avoid the aggravation of conflict if the ethical connections will be established at the following levels:

- The level of awareness. People are not always "ready to join" the achievements of culture and art, which they are offered, even if it is not the culture of another ethnic group, but of their own.

- The level of direct or indirect contact. These contacts are to be formed specifically, the more so as different people are at different stages of cultural development and all of them determine the basic assessment of the surrounding space.

- The level of conflict-free interaction

The majority of respondents identified the personal strategy of behavior in conflict situations, e.g. they named several strategies depending on the situation (Fig. 5):

Thus, although the respondents do not state explicitly, they distinguish the destructive and constructive conflicts and demonstrate a negative attitude towards destructive conflicts, i.e. to the destruction of cultural relations and the inability to solve problems. The domination of adaptative strategies is due to that:

- the subject of cultural and ethical issues does not concern a person,

- there is an awareness of the person's rightfulness and also hope for the possibility of a compromise,

- it is desirable to maintain good relations.

In the context of a multi-ethnic society there appear some archetypal mental bases expressed in the concepts of "belonging" and "our-alien". Belonging as a characteristic of the subject is defined by features of the subject's similarity to

\section{PERSONAL STRATEGY OF BEHAVIOR IN CONFLICT SITUATION}

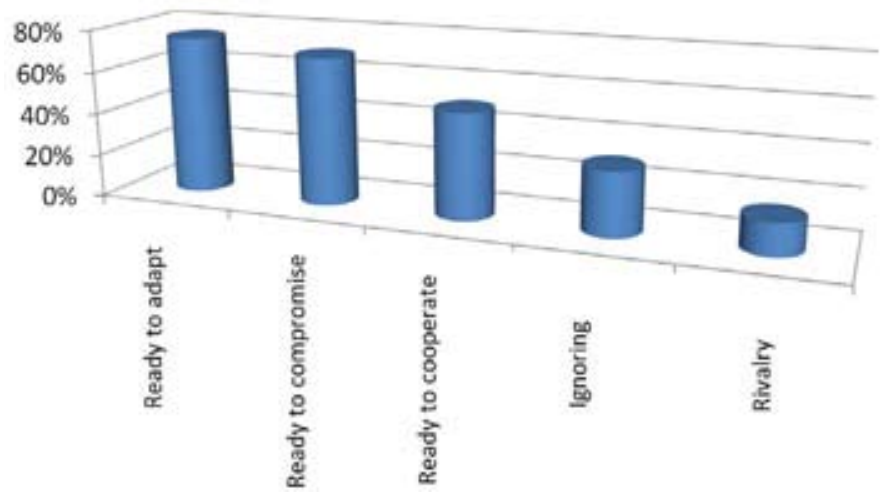

Fig.5 Personal strategy of behavior in conflict situations 
other actors, the presence of links and the need to unite. The survey revealed a variety of forms, levels, stability of the characteristic of belonging. This belonging has become a factor of assessment in the dichotomy "our-alien", a determinant of expectations, preferences, prejudices, as well as a definition of rights and responsibilities. At the same time the assessment based on criteria is uncertain, while factual assessment comes to the foreground. For the assessment based on criteria the main principles are:

- localization of life activity

- particular relationships and interactions with others

- introduced by the media special characteristics of relations

For example, belonging was in a transitional state, when in the environment there are people of several cultures and religions. The dominant factor is curiosity, an interest in another, which is not referred to as an "alien", but perceived as being in the same space with us but "unlike us". There has also been a proactive assessment as the projection of characteristics of a certain cultural space into other elements. There were notes stating that the "Mother Russia" has always had a lot of foreigners that "tortured" it, people remembered the peculiar behavior of people from the Caucasus, too. But the dominant attitude is interest and aversion to the destruction of cultural peculiarities. Media coverage of events in Ukraine, Georgia and other international conflicts creates the desire for sustainable "barrier", borders, in the construction of which the other party is guilty.

The realities of the social and cultural space of the region put the really important indicators, a kind of "moral choice" to the fore. This moral choice was found in the answers to the question: How do you feel about the festive-ceremonial culture of other nations, religions, if you have these celebrations in the place where you live? (Fig. 6).

The authors explain that respect for other cultures is an expression of respect for the culture in general, and the basis for the expectations of positive attitude to the respondents' own culture. "Plunging" into the world of another culture is always interesting, it broadens the mind, and a man enters the world of culture more thoroughly. But there are situations when the display of originality in the holidays of other nations shows cruelty: for example, during Ramadan people sacrifice a sheep publicly, and it causes negative emotions and negative reactions.

The respondents do not distinguish between the nature of the holidays: whether these are the

ATTITUDE TO FESTIVE-CEREMONIAL CULTURE OF OTHER NATION, RELIGIOUS GROUP



Fig. 6. Attitude to festive-ceremonial culture of other nations, religious group 
religious holidays or holidays dedicated to natural cycles. This probably stems from the knowledge of only the "surface" of the ritual, and ignorance of the essence of the holiday. One reason for a cultural and ethical conflict is the failure to comply with the rules and etiquette.

The next question in the list was: "How do you feel about the manifestation of feelings (kissing, hugging) in public?" The researchers got a few positions where evaluations were interspersed with clarifications: negative, positive, indifferent, depending on the aesthetic type and specification of what is permitted and what is not.

Once again age and gender indicators were not decisive. The negative attitude was accompanied by a commentary: the people who give vent to their feelings in public eye do not think about the reaction of others. It is possible for some reason that for some people it is annoying or just unpleasant to look at such scenes. To demonstrate the feelings is considered ugly, as an observer present may feel uncomfortable. Moreover, it is contrary to the traditional norms of behavior.

A significant number of respondents (about a half) expressed some another point of view. "It is nice to see people who love, it brings a smile". "It is good if people share the joy with others". At the same time, virtually all respondents worried about ethical side of this relationship. It depends on what the meaning of the kisses and hugs is. "Kissed the lady's hand", a friendly hug are not beyond the bounds of decency. In general, if public kissing and hugs are "not associated with sex", they are quite acceptable. Kissing of homosexuals is assessed negatively, as this is a demonstration of somewhat untraditional in a traditional society.

Along with attention to interpersonal cultural and ethical conflicts the respondents turn to personal reflection (self-reflection). When the respondents were asked to recall instances where perhaps they may have not acted quite ethically in relation to another person, $98 \%$ of respondents described their actions in relation to relatives or colleagues. This indicates a high level of self-criticism of the respondents. In addition, almost all (except 2\%) answered that they feel sorry about what happened, but in most cases the factor of irreversibility is undeniable, so they feel impossible to turn the clock back and therefore more moral actions will become possible only in the future, and in relation to other people.

Thus, the coding mechanisms of cultural meanings in various artifacts and deciphering these meanings during the life of the individual is of particular importance. Specification of representations about the content and nature of the values indicates the ambiguous understanding of a structure of personal values by modern residents of the Krasnoyarsk Territory. It can be argued that the definition of life-purpose act as a natural and necessary element of life is a part of their worldview. The complex of value orientations, norms, attitudes of the respondents meets the traditional in the Russian society representation of the priority of moral values and the need for tolerance towards manifestations of a foreign culture and, at the same time, the rejection of open defiance of the existing ethical rules and regulations. There are signs of a rational and pragmatic type of culture, in a way contrary to the Russian mentality. Due to the high importance of ethical component for characterizing social and cultural space there appear unindifferent attitude of the respondents to the cultural and ethical relations, and possible ways to stabilize and harmonize them. The realities of the social and cultural space of the Krasnoyarsk Territory bring the really important indicators, a kind of "moral choice" to the fore. 


\title{
References
}

1. Morozova, O.F., Nozdrenko, E.A. (2014). Dosugovaia deiatel'nost' kak factor razvitiia sotsiokul'turnoi sredy Sibirskogo regiona [Leisure activities as a factor of developing social and cultural environment of the Siberian region]. Istoricheskie, filosofskie, politicheskie i iuridicheskie nauki, kul'turologiia i iskusstvovedenie. Voprosy teorii i praktiki (Historical, philosophical, political and legal sciences, cultural studies and art history. Issues of theory and practice), 10. Tambov: Publishing House "Gramota". Pp.148-150.

2. Nozdrenko, E.A. (2014). Formirovanie aktual'nogo sprosa na kul'turnyi dosug sredstvami reklamy [Formation of the current demand for cultural leisure facilities]. NB: Problemy obshchestva i politiki (NB: Issues of Society and Politics), 10. Pp. 81-100, available at: http://e-notabene.ru/pr/ article_13433.html. doi: 10.7256/2306-0158.2014.10.13433. URL:

3. Intellektual'nyi dosug: aktual'nye problem i perspektivy [Intelligent leisure: current issues and perspectives]. Materialy Vtorogo regional'nogo simpoziuma (Proceedings of the Second regional symposium), managing editor E.A. Nozdrenko. Krasnoyarsk: SFU, 2015, 74 p.

\section{Комплексная система ценностей современного человека: \\ по материалам социологического исследования \\ в Красноярском крае}

\author{
Е.А. Ноздренко, \\ О.Ф. Морозова, Е.А. Рукавицына \\ Сибирский федеральный университет \\ Россия, 660041, Красноярск, пр. Свободный, 79
}

В статье представлены результаты соииологического исследования в рамках проекта по изучению феномена культуры в жизнедеятельности современного человека. Объектом исследования являются жители городов Красноярского края; предметом выступает сочиально-культурная деятельность человека по формированию ценностных ориентаиий, норм, правил существования, идей, образцов и т.д. Формат соииологического исследования личное (глубинное) интервью. Особенности выборки: неслучайная, по методу «первого встречного», количество респондентов составило 40 человек. Целью данного исследования определено выявление комплекса ценностных ориентаций, норм, установок потребителей, определяющих их смысложизненные поступки и причины формирования основных культурных иенностей в современном российском обществе.

Проблема исследования, с одной стороны, состоит в рассогласованности запросов человека $\kappa$ культуре, формирующей его как «продукт», и возможностей культурного пространства; с другой - в необходимости формирования запросов «человека культурного», определении «правильного» пути сочиализаџии граждан общества, в формировании таких ценностных ориентаций, которые не только давали бы возможность человеку существовать в рамках современного общества, но и вызывали бы постоянное желание самореализаиии, самосовершенствования, саморазвития, а также желание преобразования окружающего пространства средствами сочиально-культурной деятельности.

По результатам исследования конкретизация представлений о содержании и характере иенностей свидетельствует о неоднозначном понимании респондентами структуры 
ценностей личности. Определение смысложизненных поступков стало составляющей мировоззрения респондентов. При этом само их наличие не подвергается сомнению, воспринимается как естественный и необходимый элемент жизнедеятельности. Встречаются признаки рачионально-прагматического типа культуры, некоторым образом противоречащиероссийскойментальности.Всвязисвысокойзначимостьюэтическоговектора для характеристики соииокультурного пространства следует отметить небезразличное отношение респондентов к культурно-этическим отночениям, их стабилизации и путям их гармонизачии. В условиях многоначионального общества проявились архетипические основания менталитета, выраженные в понятии «принадлежность», в конщепте «свойчужой». В статье определены уровни этических связей с иелью избегания обострения конфликтной ситуации. Реалии социокультурного пространства Красноярского края на первый план ставят действительно важные показатели, появляется своеобразный «нравственный набор».

Ключевые слова: система иенностей, культура, смысложизненный поступок, социальнокультурное пространство, Красноярский край, глубинное интервью.

Исследование проводилось при финансовой поддержке в рамках ФБГУ «Российский гуманитарный научный фонд» (№ проекта 14-13-24002) и КГАУ «Красноярский краевой фонд поддержки научной и научно-технической деятельности» (№ проекта КФ-458). на тему «Интеллектуальный досуг как фактор устойчивого развития сочиально-культурной среды урбанизированной территории (на материале Красноярского края)».

Научная специальность: 24.00.00 - культурология. 